\title{
THE PRODUCTION OF PRECIPITINS BY THE FOWL
}

\author{
LUDVIG HEKTOEN \\ From the Memorial Institute for Infectious Diseases, Chicago
}

The rabbit is used almost exclusively for the production of precipitins for the identification of blood and other proteins. Of the usual laboratory animals it is regarded as by far the best for this purpose, but of course it is not the only animal that can produce precipitins in large amounts. For example, the serum of persons who have been injected with antidiphtheria serum may contain antihorse precipitins in high concentration for some days. This observation indicates that man may be a good precipitin producer. We have another example in the domestic fowl which responds to the injection of foreign blood or serum with precipitin formation just as regularly and readily as the rabbit, if not more so, as observed by Sutherland and shown also in the experiments about to be described.

The only observer to use fowl precipitins on a large scale in the identification of blood seems to be Sutherland ${ }^{1}$ in India, but Ewing ${ }^{2}$ was the first to use this animal in such work, and Uhlenhuth ${ }^{3}$ also records some special observations on precipitin formation by fowls.

Sutherland describes his method of immunization as follows: "On the first day of treatment the fowl receives $5 \mathrm{c} c$ of the serum of man or a domestic animal, injected into the right wing-vein, after careftl disinfection of the site of puncture by means of a pledget of cotton wool soaked in ether. On the 4th day $10 \mathrm{c} \mathrm{c}$ are injected into the left wing-vcin. On the 8 th day $10 \mathrm{c} \mathrm{c}$ are injected into the peritoneal cavity When feline serum is used the dosage is 4,8 , and $8 \mathrm{cc}$, as it is found that the fowls readily succumb to larger doses. On the $22 \mathrm{nd}$ or $23 \mathrm{rd}$ day the fowl is bled into a sterile Erlenmeyer flask, which is left in the ice-chest for 24 hours. The serum that has exuded from the clot is then decanted, and tested as to its precipitin content's strength and specifity."

Received for publication Jan. 22, 1918.

1 Scientific Memoirs of Offcers of the Medical and Sanitary Departments of the Govern. ment of India, No. 39, 1910. Indian Jour. Med. Research, 1915, 3, p. 216.

2 Med. News, 1903,83, p. 871.

s Kolle u. Wassermann's Handbuch, 1913, 3, p. 264. 
I have followed this method with good result. In many cases a single intravenous injection of 10-20 c c of blood, defibrinated or citrated, or serum may give just as good results, but such injections may result in sudden death. I find further that a single intraperitoneal injection of $20-30 \mathrm{c}$ c of defibrinated blood or serum in most cases is followed by a fairly abundant production of precipitin. In the case of cat and rat blood, however, a single injection is hardly enough, but two or more injections 4-6 days or so apart are necessary to bring the precipitin-content up to a satisfactory titer. As would be expected, pigeon blood has only limited antigenic effect in fowl. Injected intraperitoneally in quantities not exceeding $20 \mathrm{c} \mathrm{c}$ cat blood has been without serious ill effects, but it has caused more disturbances than any other kind of blood.

After a single injection of foreign blood or serum there takes place a gradual accumulation of precipitin in the blood of the fowl, the high point being reached about 9-12 days after the injection; before long the precipitin-content begins to fall, the normal or nearly normal level being reached in some cases as early as the 20th day, in other cases not until the 60th day or longer. The curve described by the precipitin under these conditions is a typical antibody curve. When severaI injections are given, the precipitin titer of the serum fluctuates more or less, usually falling after each injection and rising in a few days somewhat higher than the previous high level. Speaking generally, the best time to bleed to obtain the most potent serum is 9-12 days after the last injection. So far nothing has appeared which would indicate that in the modes of antibody-production the fowl differs in any essential particular from other, in this respect, better studied animals. There is more or less individual variation in the power to produce various precipitins, but it seems to me distinctly less so than in the rabbit and this is particularly true in my experience so far with respect to precipitins for human blood. Of the 27 chickens I have injected with human blood or serum, all but 2 gave a precipitin titer of the serum of 12,000 or higher, i. e., the serum produced precipitate in dilutions of human blood of $1: 12,000$ or more of salt solution. Three of these animals were immunized by Sutherland's method; 9 received single intravenous injections of $12-20 \mathrm{c} c$ of serum or $25 \mathrm{c} \mathrm{c}$ of blood; and 15 received single intraperitoneal injections of $20 \mathrm{c} \mathrm{c}$ of blood. The two failures were in the last group. From these results it seems quite certain that the fowl is a more reliable and more uniformly liberal producer of antihuman precipitin than the rabbit. 
For the production of precipitating serum for practical purposes, roosters rather than hens should be used because the serum of roosters as a rule does not contain nearly so much free fat as hen serum, which often is not clear on that account. Young nearly full-grown animals are preferable.

The blood must be collected in as sterile condition as possible. The serum, withdrawn either after the clotted blood has been standing some hours or after centrifugation, should be wholly free from red corpuscles and should be left standing in the cold box for some days before it is used, in order that whatever spontaneous precipitate forms may have time to settle.

As pointed out by Sutherland and Mitra ${ }^{4}$ fowl antiserum may give rise to rather prompt reactions in high dilutions of heterologous serums. They found that such nonspecific reactions would occur especially when antiserum kept in a frozen state had been thawed rapidly, due they suggest to modifications in the electric charge of colloid molecules of the antiserum. If the thawing were effected gradually as at room temperature in cold weather and in the ice-chest in hot weather, nonspecific reactions were not observed. These investigators also found that the growth of bacteria or moulds in the antiserum may lead to nonspecific reactions.

I find that with the ustual salt content of about $0.9 \%$, fowl antiserum is liable to give rise to nonspecific reactions even when the explanations advanced by Sutherland and Mitra are not applicable and that precipitate then usually forms also in mixtures of antiserum with $0.9 \%$ salt solution only. With uncontaminated serum allowed to remain at room temperature for 2 hours or so after being removed from the icebox, apparently all nonspecific reactions are avoided easily by the simple expedient of making the salt content of all blood or serum dilutions used in the tests $1.9 \%$ instead of $0.9 \%$. Consequently in all practical work with fowl antiserum these special precautions should be used to avoid all misleading nonspecific reactions.

Table 1 gives the titers of a number of different kinds of antiserums, most of them developed by a single intraperitoneal injection. The figures on the table as well as on the curves give the highest dilution in $1.8 \% \mathrm{NaCl}$ solution of laked blood, the salt content having been restored, in which the antiserum produced distinct precipitate after one hour at room temperature.

The tests were made in small tubes by the contact, ring or zonal method, that is to say, small quantities of antigen-dilutions having

- Indian Jour. Medical Research, 1914, 1, p. 707. 
been placed in tubes, about $0.1 \mathrm{c} \mathrm{c}$ of antiserum is introduced in each tube at the bottom, by means of capillary pipets, so that a well defined plane of contact is formed by the two fluids.

In practically all the instances shown in the table, in which an antiserum was tested with its proper antigen, a layer of precipitate formed

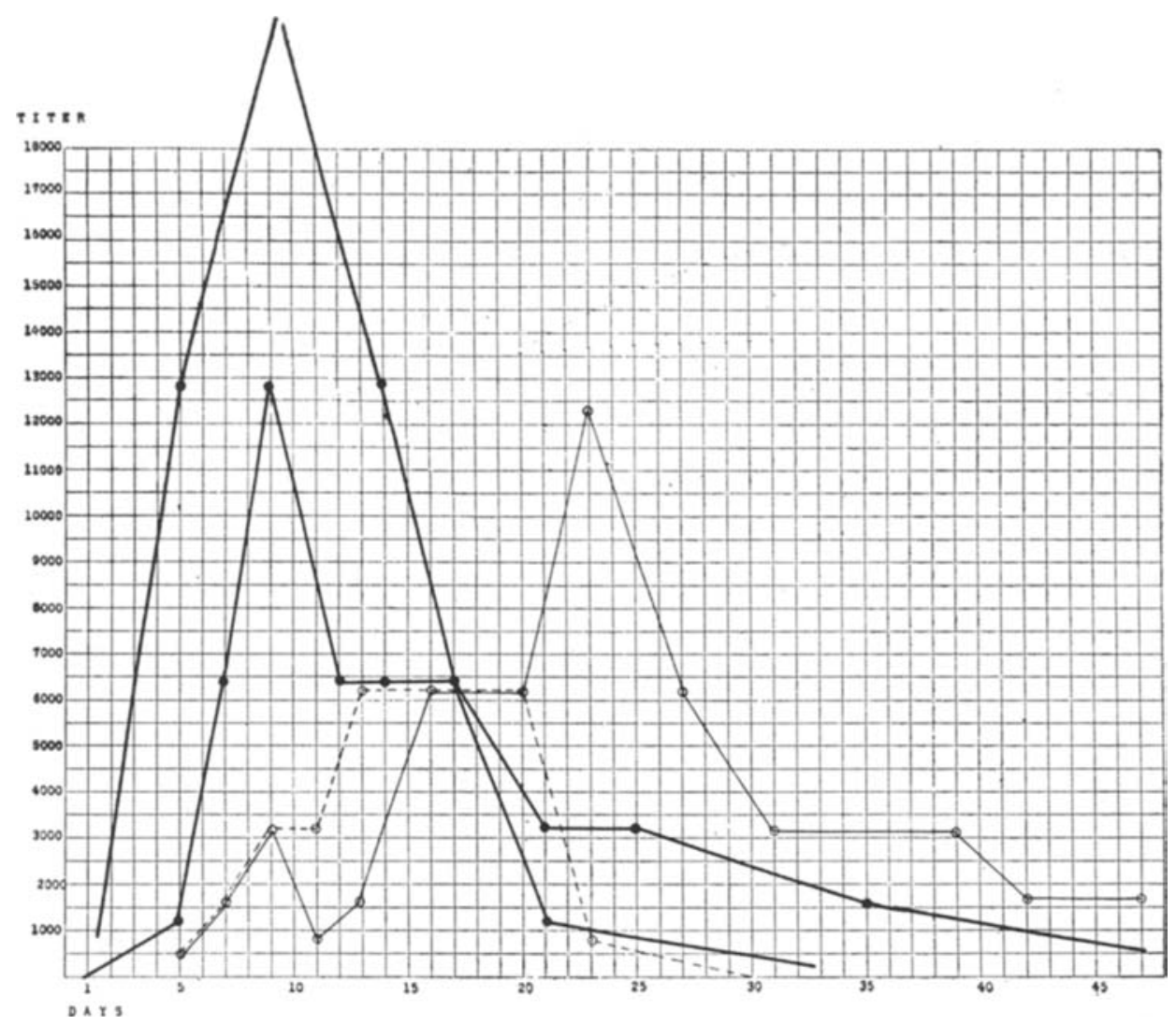

\footnotetext{
Chart 1.-Precipitin curves in fowls. The heavy black lines show the course of precipitins for human blood in 2 fowls, each injected intraperitoneally with $20 \mathrm{c} c$ of human blood on the 1st day.

The solid fine line indicates the precipitin for rabbit blood in a fowl injected intraperi. toneally with $20 \mathrm{cc}$ rabbit blood on the 1 st day, and reinjected in the same way on the 10th day. The broken fine line shows the precipitin in a fowl injected intraperitoneally with $20 \mathrm{c}$ c rabbit blood on the 1st day only.
}

almost at once in all dilutions up to 1 in 1,000, and even higher; and as a rule, in the dilutions recorded as marking the limit of precipitating action, in other words giving the titer of the antiserum, precipitate would appear within 20 minutes. On the other hand, in tests with 
blood other than that used in the production of particular antiserum, whatever precipitate formed would form more slowly and with a few exceptions in low dilutions only.

The generally accepted standard of potency for precipitating serum is a reaction within a minute or two in a $1: 1,000$ dilution of its homologous serum or blood in salt solution; and the standard of specificity is that no reaction occurs in any heterologus serum or blood dilution except after 20-40 minutes or longer, and then only in the lower dilutions. Viewed in the light of these standards, the results of my observations establish that it is an easy matter to obtain from the fowl precipitating serum of the strength and specificness required for practical purposes. As pointed out already, this is certainly true

TABLE 1

Precipitin Titers of Fowl Antiserums

\begin{tabular}{|c|c|c|c|c|c|c|c|c|c|c|c|c|}
\hline Antiserums* & $\begin{array}{c}\text { Beef } \\
\text { Blood }\end{array}$ & $\begin{array}{l}\text { Cat } \\
\text { Blood }\end{array}$ & $\underset{\text { Blood }}{\text { Dog }}$ & $\begin{array}{l}\text { Goat } \\
\text { Blood }\end{array}$ & $\begin{array}{c}\text { Guinea- } \\
\text { pig } \\
\text { Blood }\end{array}$ & $\begin{array}{l}\text { Horse } \\
\text { Blood }\end{array}$ & $\underset{\text { Blood }}{\text { Human }}$ & $\begin{array}{c}\text { Rabbit } \\
\text { Blood }\end{array}$ & $\underset{\text { Blood }}{\text { Rat }}$ & $\begin{array}{l}\text { Sheep } \\
\text { Blood }\end{array}$ & $\begin{array}{l}\text { Swine } \\
\text { Blood }\end{array}$ & $\begin{array}{c}1.8 \% \\
\text { NaCl } \\
\text { Solution }\end{array}$ \\
\hline 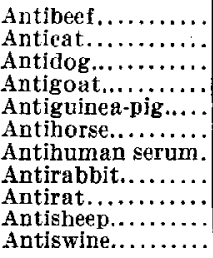 & $\begin{array}{r}12800 \\
0 \\
0 \\
6400 \\
0 \\
200 \\
200 \\
0 \\
0 \\
800 \\
0\end{array}$ & $\begin{array}{r}0 \\
6400 \\
800 \\
0 \\
0 \\
0 \\
0 \\
0 \\
0 \\
0 \\
0\end{array}$ & $\begin{array}{r}200 \\
800 \\
6400 \\
0 \\
0 \\
0 \\
0 \\
0 \\
0 \\
0 \\
0\end{array}$ & $\begin{array}{r}6400 \\
400 \\
200 \\
25000 \\
0 \\
200 \\
200 \\
0 \\
0 \\
1600 \\
0\end{array}$ & $\begin{array}{r}0 \\
200 \\
0 \\
200 \\
6400 \\
0 \\
0 \\
0 \\
0 \\
0 \\
0\end{array}$ & $\begin{array}{r}200 \\
0 \\
0 \\
200 \\
0 \\
12800 \\
0 \\
0 \\
0 \\
400 \\
0\end{array}$ & $\begin{array}{r}600 \\
0 \\
400 \\
0 \\
0 \\
200 \\
12800 \\
0 \\
200 \\
0 \\
0\end{array}$ & $\begin{array}{r}0 \\
0 \\
1600 \\
0 \\
0 \\
0 \\
0 \\
6400 \\
200 \\
0 \\
0\end{array}$ & $\begin{array}{r}0 \\
0 \\
800 \\
200 \\
0 \\
0 \\
0 \\
400 \\
6400 \\
0 \\
0\end{array}$ & $\begin{array}{r}6400 \\
200 \\
0 \\
25000 \\
0 \\
200 \\
0 \\
0 \\
0 \\
6400 \\
0\end{array}$ & $\begin{array}{r}0 \\
0 \\
0 \\
200 \\
0 \\
0 \\
400 \\
0 \\
0 \\
0 \\
12800\end{array}$ & $\begin{array}{l}0 \\
0 \\
0 \\
0 \\
0 \\
0 \\
0 \\
0 \\
0 \\
0 \\
0\end{array}$ \\
\hline
\end{tabular}

* All from single injections except cat and rat.

with respect to the most frequently used serum, the antihuman. The only marked exception to the standard of specific limitations of action of precipitating serum are the antibeef and antigoat serums. Each caused precipitates in high dilutions of the blood of the three ruminants tested-beef, goat, sheep. It is rather probable too that if the antisheep serum studied had been of a higher titer, its action on ruminant blood other than sheep would have been more pronounced. Antiruminant rabbit serum also may contain precipitins of high titer for ruminant blood or serum other than used in the immunization. Hence it may be necessary to use special methods in order to identify the blood of a particular ruminant by means of antiserum, either rabbit or fowl, but even so it might prove very difficult to distinguish between sheep and goat blood. In the case of fowl antiserum with too diffuse precipitat- 
ing action, Sutherland and Mitra ${ }^{4}$ secured good results by dilution of the antiserum with normal fowl serum.

From the results described in the foregoing it is evident that in case of necessity the fowl can be used as a substitute for the rabbit for the production of precipitating serums in general, as has been done by Sutherland in India. Wherever rabbit antiserum is available, however, it perhaps will be best in forensic work to limit the use of fowl antiserum for the present to cases which demand a definite answer to the question whether a given blood spot is rabbit blood. The fowl reacts to a single injection of rabbit blood with the prompt production of antirabbit precipitin of high titer. In two cases it proved easy by means of antirabbit fowl serum to demonstrate that certain blood spots, in one case on a newspaper and in the other on shoes, were due to rabbit blood. To distinguish between hare and rabbit blood it probably would be necessary to use special methods, such as the crossimmunization described by Uhlenhuth, who found that hares develop antirabbit precipitins on repeated injection of rabbit serum.

\section{SUMM ARY}

The domestic fowl is a prompt, reliable and liberal producer of precipitins, more so than the rabbit. A single intraperitoneal injection of $20 \mathrm{c}$ c of defibrinated blood or serum in most cases in 10-12 days yields a precipitating serum of sufficient strength and specificity for practical purposes.

On account of an unwelcome tendency to give nonspecific reactions, especially on rapid transfer from low to higher temperatures, great care must be exercised in all tests with fowl antiserum, and $1.8 \%$ salt solution should be used in making all mixtures and dilutions. 